\title{
Graft vasculopathy, rejection and mortality predic- tors in heart transplant patients
}

\author{
Jana Ljubas Maček*, Boško Skorić, Maja Čikeš, Marijan Pašalić, Željko Baričević, Jure Samardžić, \\ Ivo Planinc, Davor Miličić \\ University of Zagreb School of Medicine, University Hospital Centre Zagreb, Zagreb, Croatia
}

Purpose: We investigated pretransplant and posttransplant factors that could influence survival and development of cardiac allograft vasculopathy (CAV) and graft cellular rejection (CR) in heart transplant patients (Pts).

Methods: 120 study Pts in the follow-up 10 years, mean age $48,8 \pm 13,5$. The patient characteristics (age, gender, blood type, diagnosis, pulmonary vascular resistance PVR), transpulmonary gradient, graft ischemic time and duration of extracorporeal circulation, ECC) and pretransplant comorbidities (diabetes mellitus, chronic renal failure, hypertension, hyperlipidaemia) were analysed. Postransplant complications (postHTx hypertension, chronic renal failure — postHTx-RF, steroid diabetes mellitus - SDM) were also correlated with CAV and mortality, as well as biomarkers such as NT-proBNP and troponin T. Immunosuppressive regimens and cellular rejection were also analyzed. For statistical analysis chi-square test, student t-test and ANOVA were used (SPSS vers.21).

Results: Higher transpulmonary gradient (but not PVR) correlated significantly with higher mortality $(p=0,003)$, as well as longer ischemic time $(p=0.004)$ and ECC duration $(p=0.043)$.

Received: $1^{\text {st }}$ May 2014

*Address for correspondence: Klinički bolnički centar Zagreb, Kišpatićeva 12, HR10000 Zagreb, Croatia.

Phone: +385-98-577-707

E-mail: janaljubas@yahoo.com
PostHTx-RF ( $p=0.023)$ and SDM $(p=0.042)$ also significantly contributed to mortality. Female gender had an insignificant trend toward longer survival $(p=0.079)$. Higher NTproBNP values $(5,833$ vs $2,721 \mathrm{pg} / \mathrm{ml}, \mathrm{p}=0.025)$ significantly predicted all-cause mortality. There was a trend with higher standardized corticosteroid doses to correlate with lower CAV incidence $(p=0.129)$. NT-proBNP cut-off value of $>750$ $\mathrm{pg} / \mathrm{ml}$ has a trend to predict $\mathrm{CR}(\mathrm{p}=0.084)$. Standardized cyclosporine A concentration (CyA) less than $10 \mathrm{0ng} / \mathrm{ml}$ $(p=0.023)$ significantly correlated with $C R$ and CyA between $100-150 \mathrm{ng} / \mathrm{ml}$ had the same trend $(p=0.067)$. Other variables had no statistical significance.

Conclusions: Patient pretransplant comorbidities did not have crucial impact on posttransplant survival, expected transpulmonary gradient which proved to be a very powerful parameter influencing survival (while PVR did not). Steroid diabetes and chronic renal failure (excluding early acutisation of preexisting RF) are important postransplant comorbidities contributing to higher mortality. Immunosupression plays an important role for the CAV prevention and in our study more potent corticosteroid therapy proved to lower CAV incidence. CR rejection was not associated with higher CAV incidence, it could be predicted by higher NTproBNP levels and prevented by higher CyA concentration.

KEYWORDS: heart transplantation, vasculopathy, graft rejection, heart transplant, mortality.

CITATION: Cardiol Croat. 2014;9(5-6):233. 